\title{
Neuroprotective Effect of Acute Interferon-Beta 1B Treatment after Spinal Cord Injury
}

\author{
Omurilik Yaralanması Sonrası Akut Interferon Beta 1 Tedavisinin \\ Koruyucu Etkisi
}

Goksin SENGUL ${ }^{1}$, Mustafa Kemal COBAN ${ }^{1}$, Murteza CAKIR ${ }^{1}$, Suleyman COSKUN $^{1}$, Hulya AKSOY², Ahmet HACIMUFTUOGLU ${ }^{3}$, Fatih SARUHAN ${ }^{3}$, Muhammed CALIK ${ }^{4}$

${ }_{1}^{1}$ Ataturk University, Faculty of Medicine, Department of Neurosurgery, Erzurum, Turkey

${ }^{2}$ Ataturk University, Faculty of Medicine, Department of Biochemistry, Erzurum, Turkey

${ }^{3}$ Ataturk University, Faculty of Medicine, Department of Pharmacology, Erzurum, Turkey

${ }^{4}$ Ataturk University, Faculty of Medicine, Department of Pathology, Erzurum, Turkey

Correspondence address: Goksin SENGUL / E-mail: goksinsengul@gmail.com

\begin{abstract}
AIM: The purpose of this trial was to investigate the effect of a well known immunomodulator -interferon beta- on traumatized spinal cord in terms of biochemical and histopathological features.

MATERIAL and METHODS: Twenty-four rats were used in this trial. The rats were divided into 3 groups. In the first group of rats, spinal cord injury was created by the weight drop method and interferon beta was administered. In the second group, physiological saline was administered. Third group was used as control. Rats were sacrificed 24 hours following trauma. Heat shock protein 70 levels were measured in the spinal cord samples and the samples were examined histopathologically.

RESULTS: When the rats in the physiological saline and control groups were compared to rats treated with interferon beta $1 \mathrm{~b}$, those treated with interferon beta $1 \mathrm{~b}$ revealed significant increases in the heat shock protein 70 levels in tissues, and histopathological examination revealed decreases in polymorphonuclear leucocyte infiltration, haemorrhage, oedema and necrosis.

CONCLUSION: Although, the results of the study indicated that interferon beta might have some healing effects via increasing the cellular heat shock protein 70 on spinal cord injuries, more studies are needed.
\end{abstract}

KEYWORDS: Heat shock protein 70, Interferon beta, Spinal cord injury

ÖZ

AMAÇ: Bu çalışmanın amacı, immunomodülatör olduğu bilinen interferon betanın travmaya uğramış omurilikteki etkisini biyokimyasal ve histopatolojik olarak araştırmaktır.

YÖNTEM ve GEREÇLER: Bu çalışmada, 24 adet rat kullanıldı. Ratlar rastgele 3 gruba ayrıldı. Birinci gruptaki ratlarda ağırlık düşürme yöntemi ile omurilik travması oluşturularak interferon beta verildi. İkinci gruptaki ratlarda serum fizyolojik verildi. Üçüncü grup kontrol olarak kullanıldı. Denekler travmadan 24 saat sonra sakrifiye edildi. Alınan omurilik örneklerinde ısı şok proteini 70 düzeyleri ölçüldü ve örnekler histopatolojik olarak incelendi.

BULGULAR: İnterferon beta $1 \mathrm{~b}$ ile tedavi edilen ratlarda doku düzeyinde ısı şok proteini 70 düzeyinin serum fizyolojik verilen ratlara ve kontrollere göre belirgin olarak arttığı ve histopatolojik olarak polimorfonüklear lökosit infiltrasyonun, hemorajinin, ödemin ve nekrozun azaldığı gözlendi.

SONUÇ: Çalışmadan elde edilen veriler, interferon betanın travmatik omurilik yaralanmasında hücre seviyesinde ısı şok proteini $70 \mathrm{i}$ artırarak iyileştirici etkisi olabileceğini göstermekle beraber daha ileri çalışmalara ihtiyaç vardır.

ANAHTAR SÖZCÜKLER: Isı şok proteini 70, İnterferon beta, Omurilik yaralanması

\section{INTRODUCTION}

Despite significant advances in medical and surgical treatment, and enhanced comprehension of pathophysiology in spinal cord injuries, an effective treatment to prevent or treat the loss of functions due to spinal cord injuries has not been discovered yet. The pathophysiology of spinal cord injury starts with a primary mechanical injury which destroys the axons, blood vessels and cell membranes. This primary mechanical injury is followed by a second injury phase during which vascular destruction, oedema, ischemia, exitotoxicity, electrolyte instabilities, production of free radicals, inflammation and late apoptotic cell death are observed. Since primary injury is inevitable, studies concentrate on preventing secondary injuries $(3,10,15,17)$. 
Heat shock proteins are molecular structures that are located in intracellular compartments of all cells. They are found in the mitochondria and endoplasmic reticulum of cells (11). During stress situations at cellular level, these proteins are increased in number and they assist in increasing the cellular stability and maintaining survival by enabling appropriate folding of proteins. It was suggested that in spinal cord injuries, heat shock protein 70 binds to Apaf-1 and inhibits caspase 9 activation, and it also inhibits apoptosis by playing a key role in the regulation of secondary injury mechanisms (11). In addition, heat shock protein 70 displays an effect on the regulation of the inflammatory response, which is one of the secondary injury mechanisms $(4,7,8,11,21,22)$.

Interferon plays a role in the activation of a number of functions in the immune system and the inflammatory response and it has been reported to assist in maintaining tissue integrity in loci of lesions after spinal cord injuries (6). In this trial, we investigated the role of heat shock protein 70 on clarifying the mechanism of action of interferon.

\section{MATERIAL and METHODS}

This study was conducted at the Medical Experimental Research Center, Ataturk University. The Ethical Committee of Ataturk University approved the study protocol. All procedures were performed in accordance with the National Institute of Health Principles of Laboratory Animal Care.

In this trial, 24 male Sprague-Dawley rats, weighing 190$220 \mathrm{gr}$, were used. The rats were randomly divided into three groups, namely the interferon group, the physiological saline group and the control group. Prior to the trial, the rats were kept under laboratory conditions at $20-24^{\circ} \mathrm{C}$ and subjected to sleep/wake cycles, with no limitations in food and water for 10 days. After a 6-hour fasting period, the neurological scores and weights of all subjects were recorded prior to the surgical procedure. General anesthesia was administered to all subjects by intraperitoneal $25 \mathrm{mg} / \mathrm{kg}$ thiopental sodium (Pental Sodyum, I.E. Ulagay, Istanbul, Turkey) and the rats were placed in the prone position. Following skin incision at the T6-T11, the paravertebral muscles were dissected and laminectomy was performed between T7 and T10. No trauma was created in the control group. In the remaining groups, spinal cord injury with a power of $50 \mathrm{gr}-\mathrm{cm}$ was implemented using the weight-drop method while the dura was intact. After surgical and trauma interventions, the layers were closed appropriately. In the interferon group, two doses of interferon beta 1b (IFN $\beta 1 \mathrm{~b}$ )(betaferon, Schering, Istanbul, Turkey) was administered, one dose of 10.000 .000 IU i.p. given immediately after trauma and a second dose of 5.000 .000 IU i.p. 4 hours after trauma. The functional evaluations were performed 24 hours following surgery. In the functional clinical evaluation, the scala described by Tarlov was used for the subjective clinical evaluation (14) and the oblique plane method of Rivlin and Tator (12) was used for the objective clinical evaluation. The rats were then sacrificed by administration of $50 \mathrm{mg} / \mathrm{kg}$ thiopental sodium and spinal cord tissue samples containing at least $1 \mathrm{~cm}$ of trauma region were obtained. A portion of these spinal cord samples was immersed in liquid nitrogen and placed in the deep freeze at $-80 C^{\circ}$ for biochemical examination. The remaining samples were placed in $10 \%$ formaldehyde for histopathological examination.

Among the sample blocks which were separately labelled and immersed in paraffin, a minimum of 4 cross-sections of 4 micron were prepared and these were stained with hematoxylin-eosin. The prepared samples were examined under BX.50 Olympus light microscope with Sony DXC390P camera attached. Neuron degeneration, haemorrhage, oedema and inflammatory cell ratios in preparations were examined by modifying according to the scala developed by Wahl et al. (19). In the scoring of injury, the ratio of injured region to the whole area was calculated and scoring was made as follows: 0 point in case of no injury, 1 point for injury of less than $25 \%$, 2 points for injuries between $25 \%-75 \%$, and 3 points for injuries between $75 \%-100 \%$.

For biochemical examination, the tissue was placed in a mortar and pulverized by a hammer. An appropriate volume of commercial kit Extraction Reagent was added to the tissue, which is manufactured to produce rat heat shock protein 70 , to which protease inhibitor was added. Tissue suspension was mixed to obtain a homogenous solution. The extract was transferred to a polypropylene tube and centrifuged for 10 minutes at $21000 \mathrm{~g}$ in microfuge at $4^{\circ} \mathrm{C}$. The supernatant rat heat shock protein 70 was analyzed by the ELISA kit and calculated per wet tissue; hence, the results were provided as heat shock protein $70 \mathrm{gr} /$ wet tissue.

The windows compatible SPSS ( version 13.0) program was used for the statistical analysis. The Mann-Whitney $U$ test was used for analysis of binary comparisons of the obtained HSP 70 and the objective examination findings, while triple comparisons were performed by the Kruskal Wallis test. Histopathological and subjective examination values were analyzed using the Chi-square test. Meantstandard error (Mean \pm SEM) was used. In the inter-group correlations, a $p$ value of $<0.05$ was accepted as significant.

\section{RESULTS}

Upon evaluation of subjective examination findings after 24 hours, considerable improvement was seen in the neurodeficits in the group treated with interferon when compared to the physiological saline group, and comparison of the scores of both groups revealed a statistically significant difference $(p<0.01)$. According to evaluation of objective examination after 24 hours, trauma was observed to considerably decrease the degree of the oblique plane when compared to control group $(p<0.05)$. On the other hand, it was determined that treatment with interferon beta (IFN $\beta$ ) did not increase the degree of the oblique plane.

In the physiological saline group, haemorrhage, oedema, neuron degeneration and a significant increase in inflammatory cells were observed in the histopathological evaluation (Figure 1). In the interferon group, oedema, neuron 
degeneration and a considerable increase in inflammatory cells were determined (Figure 2). A statistically significant difference was found when these two groups were compared $(p<0.05)$.

In the biochemical evaluation, the heat shock protein 70 level was found to be significantly increased in the physiological saline group when compared to the control group. A statistically significant difference was found between the two groups $(p<0.05)$. The heat shock protein 70 level was found to be significantly increased in the interferon group when compared to the physiological saline and the control groups $(p<0.05)$. The mean heat shock protein 70 levels of three groups have been presented in (Figure 3).

\section{DISCUSSION}

As a result of spinal cord injuries, many patients are confined to bed or become dependent on other individuals, or they

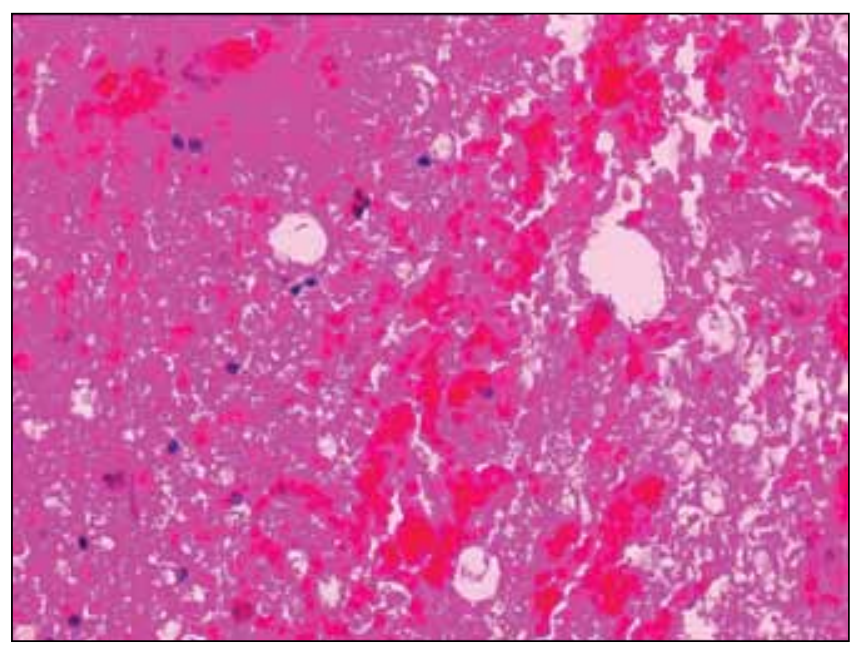

Figure 1: Appearance of spinal cord cross-section in the physiological saline group under the light microscope (HematoxylinEosin 20X).

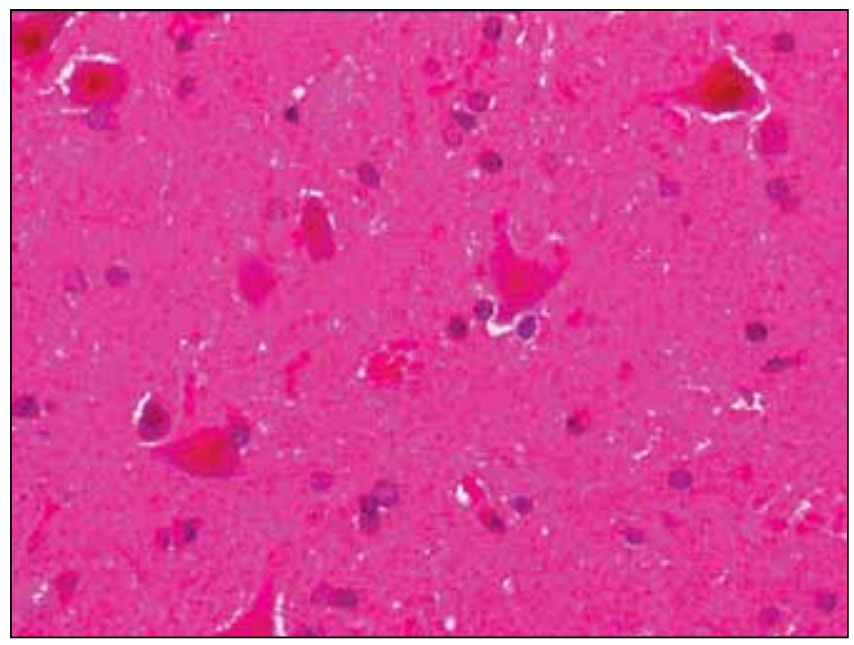

Figure 2: Appearance of spinal cord cross-section in the interferon group under light microscope (Hematoxylin-Eosin 20X). may even lose their lives. A number of trials have been performed since many centuries, starting from ancient Egypt until today, to overcome this critical situation with negative psychological, economical and social implications, and the neurological sciences community has not been able to develop a universally accepted treatment protocol and it is still not possible to prevent the complications of these injuries.

It is impossible to prevent the primary injury. Therefore, treatment strategies in spinal cord injuries concentrate on prevention of secondary injury $(3,15)$. However, currently, there is no universally accepted treatment protocol with proven neuroprotective efficacy in clinical practice.

In this trial, IFN $\beta 1 \mathrm{~b}$ was used, which is in clinical use with proven efficacy in decreasing relapse and remissions in the treatment of multiple sclerosis (18). The neuroprotective efficacy has been targeted to be achieved with this treatment by decreasing apoptosis, oedema and inflammation at tissue level during the secondary injury process after spinal cord injuries. Based on the hypothesis that IFN $\beta$ exerts this neuroprotective effect by further increasing the heat shock protein 70 levels in the intracellular compartment, which normally show an increase under stress conditions, the correlation between IFN $\beta 1 \mathrm{~b}$ and the heat shock protein 70 level was analyzed.

Heat shock protein 70 is present in structures of all cells and they play an important role in survival. They assist in appropriate folding and stabilization of intracellular proteins, help in transferring of proteins in the endoplasmic reticulum, in the mitochondria and in the cytoplasm, and last of all, they improve the cellular stability by inhibiting the inappropriate proteins in cells under stressful conditions $(5,11,20)$.

The cellular protective effect of heat shock protein 70 is not solely due to stabilization of protein structures; it has also been reported that they provide contribution to antiapoptotic

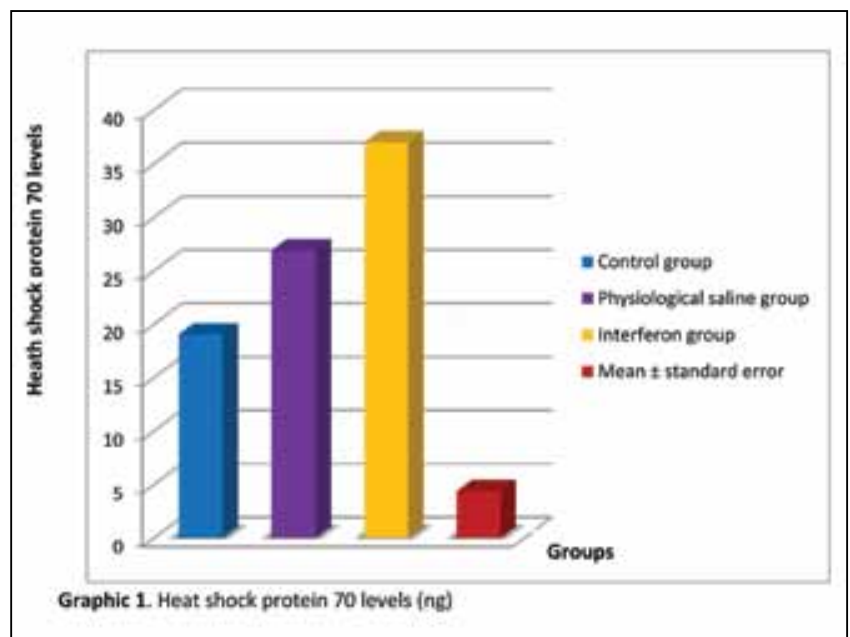

Figure 3: Mean heat shock protein 70 levels in the three groups. 
and anti-inflammatory processes. Heat shock protein 70 inhibits the caspase- 9 activation through binding to Apaf-1; thus, caspase- 3 is not activated due to caspase- 9 inactivation and the apoptotic process is interrupted. In addition to this mechanism, it has been suggested that heat shock protein 70 prevents apoptosis by increasing the secretion of bcl-2 protein, an antiapoptotic protein which inhibits the secretion of apoptosis induction factor by the mitochondria $(2,5,20$, 21).

Heat shock protein 70 also shows an anti-inflammatory effect by decreasing the tumor necrosis factor-alpha level, a protein which increases the transfer of inflammatory cells to loci of the lesion (21). In a trial conducted by Gok B et al. (6), it was shown that IFN $\beta$ administered after spinal cord injuries had decreased the inflammation at the site of the lesion and this finding was further supported by the decrease of the myeloperoxidase (MPO) level in the loci of lesion. Unfortunately, no information on the anti-inflammatory mechanism of IFN $\beta$ was provided in this trial. In view of these data, we hypothesized that the antiapoptotic and the antiinflammatory mechanisms of action of IFN $\beta 1 \mathrm{~b}$ may be due to an increase in the heat shock protein level, and by measuring the heat shock protein 70 level after spinal cord injuries, we analyzed the correlation between IFN $\beta 1 \mathrm{~b}$ and the heat shock protein 70 level.

In the trial performed by Ohta $S$ et al., the neuroprotective effects of edaravone were investigated in young adult male Sprague-Dawley rats, after creating a spinal cord injury by the weight drop model. The functional analysis process was implemented weekly for 6 weeks and in the Basso-BeatieBresnahan(BBB) locomotor evaluation, the BBB scores were found to be higher in subjects treated with edaravone when compared to the control group (9). In our trial, spinal cord injury was created by the weight drop model and objective evaluation of subjects to whom IFN $\beta 1 \mathrm{~b}$ was administered as a neuroprotective agent showed that after 24 hours, no significant difference was present when compared to the trauma group. Therefore, it was concluded that even though no early functional improvement was present, neuroprotective agents may show functional improvement after several weeks.

In a trial conducted by Gok B et al., 5 groups were constituted, each containing 8 rats. Experimentally, a pressure with a power of $50 \mathrm{gr} / \mathrm{cm}$ was implemented onto the rat spinal cords using the weight drop method and a spinal cord injury was created; the IFN $\beta$ group, the methylprednisolone sodium succinate (MPSS) group and the other groups were comparatively evaluated 24 hours after trauma. In the post-traumatic biochemical analysis, it was observed that myeloperoxidase (MPO) and lipid peroxidation (LPO) levels decreased significantly in the MPSS and in the IFN $\beta$ groups when compared to the control group, but IFN $\beta$ was found to be more effective in this regard. In the histopathological evaluations, an almost normal structure was determined in the spinal cords, apart from mild haemorrhage, oedema and necrosis. In conclusion, this trial performed by Gok B et al. showed that IFN $\beta$ administration in rats improved the clinical results and that decreasing the MPO and LPO levels were effective in preserving the spinal cord structures (6).

In the present trial, 24 hours after experimental spinal cord injury in rats realized using the weight drop method, the biochemical findings of spinal cord samples showed that the heat shock protein 70 level significantly increased in the IFN $\beta 1$ b group when compared to the trauma group and this effect led to a decrease in apoptosis during the secondary injury process and resulted in a mild prognosis of spinal cord injury. We believe that the increase in the heat shock protein 70 level determined following administration of IFN $\beta 1 b$ after trauma provides a contribution in preserving the spinal cord structure, rather than the decrease in MPO and LPO levels, as indicated in the trial conducted by Gok B et al (6). Similarly, in our trial, a decrease in neutrophil infiltration, haemorrhage, oedema and necrosis were observed in the interferon group on the histopathological examination. Upon evaluation of the subjective examination findings, a significant improvement was seen in the neurodeficits in the group treated with IFN $\beta$ and the results were statistically significant $p=0.001(p<0.05)$. On the other hand, in the objective evaluation, it was shown that IFN $\beta$ treatment did not increase the degree of the oblique planes.

In a trial conducted by Awad $\mathrm{H}$ et al. on 9 cross-bred dogs, an ischemic-reperfusion spinal cord injury was created by clamping the 4., 5., 6., and the 7. intercostal arteries and by clamping the aorta distal to the subclavian artery for 60 minutes; cerebrospinal fluid samples were evaluated for three days and it was shown that the extracellular heat shock protein 70 level in the cerebrospinal fluid increased 5.2-times while the extracellular heat shock protein 70 levels in the plasma did not change (1). This trial also indicated that the increase in the heat shock protein 70 levels under stress conditions is the defense mechanism at cellular level, and based on this view, excessive secretion of heat shock protein 70 in cases of spinal cord injuries led to increased neuroprotective efficacy. We tried to imitate this situation in our trial and found that in rats treated with IFN $\beta 1 \mathrm{~b}$ after trauma, the heat shock protein 70 level increased approximately 2 -times and the results were found to be statistically significant.

In a trial conducted by Uchida $S$ et al., cerebral ischemia was created on 32 wistar rats by occlusion of the medial cerebral artery. They evaluated the effect of geranylgeranylacetone (GGA) on cerebral ischemia in groups, each composed of 8 rats and they determined that GGA provided neuroprotective efficacy by increasing heat shock protein 70 in the rat brain tissue (16). In our trial, we observed that IFN $\beta 1 \mathrm{~b}$ treatment after spinal cord injury increased the heat shock protein 70 at the sites of lesion and we reasoned that the neuroprotective efficacy may be due to this increase.

In the trial performed by Shin $Y$ et al., spinal cord ischemia was created in 32 New Zealand white rabbits by clamping of the aorta for 25 minutes, and the neuroprotective effects of 
cyclosporine A on ischemic spinal cord injury was evaluated in groups, each composed of 8 rats. The Tarlov score was observed to be higher in rats in the cyclosporine $A$ group which were sacrificed on day 7 , when compared to the control group with no cyclosporine A and sacrificed on day 7 (13). Similarly, in our group, in which the neuroprotective agent IFN $\beta 1$ b was administered, the Tarlov scores after 24 hours were found to be higher than that of the trauma-only group which did not receive IFN $\beta$, and the difference was statistically significant $(p=0.001)$. In the rabbit model of ischemic spinal cord injury performed by Shin $\mathrm{Y}$ et al., it was concluded that administration of cyclosporine $A$ to subjects increased the levels of heat shock protein 70 and nNOS (neuronal nitric oxide synthetase), which in turn led to a decrease in the neurological deficits (13). Similarly in our trial, we believe that IFN $\beta 1 \mathrm{~b}$ treatment provides its neuroprotective effect by exerting an excessive increase in heat shock protein 70 release at tissue level after spinal cord injury.

\section{CONCLUSION}

In view of the biochemical and histopathological evaluations, decreases in post-traumatic haemorrhage, oedema, PNL infiltration and tissue necrosis in spinal cords of rats treated with IFN $\beta$ and the significant increase in the heat shock protein 70 levels indicate that IFN $\beta$ plays an important role in the neuroprotective effect. These significant results will shed light on future clinical trials.

\section{REFERENCES}

1. Awad H, Suntres $Z$, Heijmans J, Smeak D, Bergdall-Costell V, Christofi FL, Magro C, Oglesbee M: Intracellular and axtracellular expression of the major inducible $70 \mathrm{kDa}$ heat shock protein in experimental ischemia-reperfusion injury of the spinal cord. Exp Neurol 212:275-284, 2008

2. Benjamin IJ, McMillan DR: Stress (heat shock) proteins: Molecular chaperones in cardiovascular biology and disease. Circ Res 83:117-132, 1998

3. Citron BA, Arnold PM, Haynes NG, Ameenuddin S, Farooque M, Santacruz K, Festoff BW: Neuroprotective effects of caspase-3 inhibition on functional recovery and tissue sparing after acut spinal cord injury. Spine 33:2269-2277, 2008

4. Dumont RJ, Okonkwo DO, Verma S, Hurlbert RJ, Boulos PT, Ellegala DB, Dumont AS: Acute spinal cord injury, part I: pathophysiologic mechanisms. Clin Neuropharmacol 24: 254-264, 2001

5. Fink AL: Chaperone-mediated protein folding. Phisiol Rev 79:425-429, 1999

6. Gok B, Okutan O, Beskonakli E, Palaoglu S, Erdamar H, Sargon MF: Effect of immunomodulation with human interferonbeta on early functional recovery from experimental spinal cord injury. Spine 32:873-880, 2007

7. Liu XZ, Xu XM, Hu R, Du C, Zhang SX, McDonald JW, Dong HX, Wu YJ, Fan GS, Jacquin MF, Hsu CY, Choi DW: Neuronal and glial apoptosis after traumatic spinal cord injury. J Neurosci 17:5395-5406, 1997
8. Marincek BC, Kühnle MC, Srokowski C, Schild H, Hammerling G, Mombur F: Heat shock protein-antigen fusions lose their enhanced immunostimulatory capacity after endotoxin depletion. Mol Immunol 46:181-191, 2008

9. Ohta S, Iwashita Y, Takada H, Kuno S, Nakamura T: Neuroprotection and enhanced recovery with edaravone after acute spinal cord injury in rats. Spine 30:1154-1158, 2005

10. Pantoni L, Sarti C, Inzitari D: Cytokines and cell adhesion molecules in cerebral ischemia. Arterioscler Thromb Vasc Biol 18:503-513, 1998

11. Reddy SJ, La Marca F, Park P: The role of heat shock proteins in spinal cord injury. Neurosurg Focus 25:E4, 2008

12. Rivlin AS, Tator $\mathrm{CH}$ : Regional spinal cord blood flow in rats after severe cord trauma. J Neurosurg 49:844-853, 1978

13. Shin YC, Choi KY, Kim WG: Cyclosporin A has a protective effect with induced upregulation of $\mathrm{Hsp70}$ and nNOS on severe spinal cord ischemic injury in rabbits: J Invest Surg 20:113-120, 2007

14. Tarlov IM: Spinal cord compression studies III. Time limits for recovery after gradual compression in dogs. AMA Arch Neurol Psychiatry 71:588-597, 1954

15. Tator $\mathrm{CH}$, Kaptanoğlu E: Neural protection strategy after spinal cord injury. In Zileli M, Özer AF (eds), Spinal cord and Spine Surgery. Izmir: Saray Publications, 2002: 813-832

16. Uchida S, Fujiki M, Nagai Y, Abe T, Kobayashi H: Geranylgeranylacetone, a noninvasive heat shock protein inducer, induces protein kinase $C$ and leads to neuroprotection against cerebral infarction in rats. Neurosci Lett 396:220-224, 2006

17. Velardo MJ, Reier PJ, Anderson DK: Spinal cord injury. In Crockard A, Hayward R, Hoff JT (eds). Neurosurgery. USA: Blackwell Science Ltd, 2000:499-513

18. Victor $M$, Ropper $A H$ : The major categories of neurologic disease. In Wonsiewicz MJ, Medina PM, Navrazov M (eds). Principles of Neurology. New York: Mcgraw- Hill Companies, 2001: 954-982

19. Wahl F, Renou E, Mary V, Stutzmann JM: Riluzole reduces brain lesions and improves neurological function in rats after a traumatic brain injury. Brain Res 756:247-255, 1997

20. Yasuda H, Shichinohe H, Kuroda S, Ishikawa T, Iwasaki Y: Neuroprotective effect of a heat shock protein inducer, geranylgeranylacetone in permanent focal cerebral ischemia. Brain Res 1032:176-182, 2005

21. Yenari MA, Liu J, Zheng Z, Vexler Z, Lee JE, Giffard RD: Antiapoptotic and anti-inflammatory mechanisms of heatshock protein protection. Ann N Acad Sci 1053:74-83, 2005

22. Zheng L, He M, Long M, Blomgran R, Stendahl O: Pathogeninduced apoptotic neutrophils express heat shock proteins and elicit activation of human macrophages. J Immunol 173:6319-6326, 2004 